\title{
Peningkatan Kapasitas UMKM Melalui Penyusunan Business Plan
}

\author{
Dhyah Setyorini ${ }^{*}$, Sukirno ${ }^{2}$, Patriani Wahyu Dewanti3 ${ }^{3}$ Budi Tiara Novitasari ${ }^{4}$ Merinda \\ Noorma Novida Siregar5, Dian Normalitasari Purnama6
}

1,2,3,4 Prodi Akuntansi, Fakultas Ekonomi, Universitas Negeri Yogyakarta, Jalan Colombo Karangmalang, Yogyakarta, 55281, Indonesia 5, 6 Prodi Pendidikan Akuntansi, Fakultas Ekonomi, Universitas Negeri Yogyakarta, Jalan Colombo Karangmalang, Yogyakarta, 55281, Indonesia

*Email: dhyah_setyorini@uny.ac.id

DOI: $10.18196 / p p m .32 .215$

\begin{abstract}
Abstrak
Permasalahan utama yang dihadapi oleh para pelaku UMKM yang menggeluti bidang wisata di Desa Triharjo, Bantul yang tergabung dalam Pokdarwis Kedung Ngancar adalah kurangnya modal untuk mengembangkan potensi wisata yang ada. Keterbatasan penggunaan dana desa, kurangnya pemahaman mengenai seluk beluk hukum terkait pendirian dan berjalannya usaha, serta kurangnya pengetahuan mengenai cara menarik investasi menjadi kendala utama bagi Pokdarwis Kedung Ngancar untuk mengembangkan wisata Kedung Ngancar. Pengabdian masyarakat yang dilakukan untuk memecahkan permasalahn tersebut adalah dengan memberikan pelatihan penyusunan proposal bisnis untuk mengembangkan wisata Kedung Ngancar. Metode pengabdian berupa pelatihan. Melalui pelatihan ini, peserta, yaitu anggota Pokdarwis Kedungan Ngancar, diharapkan mampu mendapatkan pengetahuan tentang cara menyusun proposal bisnis sehingga dapat pengembangan modal usaha untuk wisata Kedung Ngancar. Pelaksanaan pengabdian secara umum dapat dikategorikan berhasil dilihat dari hasil evaluasi yang diberikan dan dari keaktifan peserta pada saat sesi diskusi dan tanya jawab. Peserta merasa pelaksanaan pengabdian terlaksana dengan baik dan materi yang diberikan sesuai dengan kebutuhan peserta dalam memperbaiki sistem penjaminan mutu internal. Kemampuan khalayak sasaran dalam menyusun proposal bisnis yang memadai akan berimplikasi pada masuknya investasi pengembangan Taman Wisata Kedung Ngancar. Hasil pengabdian ini menunjukkan khalayak sasaran memahami dan mengerti pentingnya menyusun proposal bisnis.
\end{abstract}

Kata Kunci: Pelatihan, Proposal Bisnis, Usaha Mikro Kecil Menengah,

\section{Pendahuluan}

Desa merupakan bagian terdekat dengan rakyat dan berhubungan dengan segala kebutuhan masyarakat. Dewasa ini, kedudukan desa semakin kuat dengan diundangkannya Undang-Undang No. 6 tahun 2014 tentang Desa (UU Desa)(Pemerintah RI, 2014). Dalam undang-undang tersebut, desa mempunyai kekuatan dalam mengelola aset desa. Kemandirian desa mulai menjadi arah prioritas pembangunan di setiap daerah. Hal ini dikuatkan dengan munculnya alokasi dana desa. Alokasi dana desa adalah dana yang dialokasikan oleh pemerintah kabupaten/kota untuk desa yang bersumber dari bagian dana perimbangan keuangan pusat dan daerah yang diterima oleh kabupaten/kota. Dengan dana desa tersebut, desa diharapkan mampu mengelola desa beserta asetnya untuk mendapatkan pendapatan asli desa (PAD). Penggunaan dana desa dapat dialokasikan ke berbagai sektor untuk memajukan Desa. Dana desa memberi kontribusi besar terhadap daya tahan ekonomi pedesaan. Penurunan angka pengangguran di pedesaan menjadi bukti kontribusi dana desa terhadap daya tahan ekonomi pedesaan, khususnya terkait dengan pertumbuhan Usaha Mikro Kecil dan Menengah (UMKM) di pedesaan. Jumlah angka pengangguran desa pada akhir periode pertama Presiden Joko Widodo tercatat hanya 3,72\% dari total (rmco.id, 2020). Angka tersebut lebih sedikit jika dibandingkan dengan angka pengangguran perkotaan yang mencapai $6 \%$. Keberhasilan penekanan angka pengangguran desa ini tidak lepas dari pertumbuhan UMKM di desa. Data semester I tahun 2019 menunjukkan jumlah UMKM skala besar 5.550 unit, UMKM skala menengah 60.720 unit, UMKM skala kecil 783.132 unit, dan UMKM skala mikro 63,5 juta unit. Jika omzet UMKM skala mikro naik sebesar 30\% dan UMKM skala kecil naik 10\% maka diharapkan ekonomi nasional akan tumbuh 
7-9\% (rmco.id, 2020). Menurut Menteri Desa, Pembangunan Daerah Tertinggal, dan Transmigrasi (Mendes PDTT), dana desa menjadi satu-satunya cara untuk memastikan desa tahan terhadap gejolak ekonomi global akibat perang dagang dan pandemi Covid-19 (rmco.id, 2020). Selama lima tahun terakhir, secara masif pemerintah telah mengeluarkan dana desa untuk pembangunan infrastruktur di pedesaan. Dengan infrastruktur yang memadai, pembangunan pedesaan selanjutnya difokuskan pada peningkatan Sumber Daya Manusia (SDM). Peningkatan SDM diharapkan menjadi langkah awal untuk meningkatkan pertumbuhan UMKM. Beberapa aspek penting dalam peningkatan UMKM antara lain strategi pemasaran, pemenuhan bahan baku yang optimal, dan pendanaan. Alokasi penggunaan dana desa tersebut lebih lanjut diatur dalam Peraturan Mendagri Nomor 20 tahun 2018. Lebih lanjut dijelaskan pada Pasal 17 ayat 2 poin $\mathrm{h}$ bahwa salah satu penggunaan dana desa dapat dialokasikan ke sektor pariwisata. Hal inilah yang menjadi dasar bagi kepala desa di seluruh Indonesia untuk berinovasi terkait pemanfaatan dana desa di sektor pariwisata. Salah satu pemanfaatan dana desa di sektor pariwisata adalah dengan dilakukannya pengembangan desa wisata. Pengembangan desa wisata membawa dampak yang positif bagi perkembangan ekonomi masyarakat lokal di Desa. Hermawan (2016) menyatakan bahwa adanya pengembangan desa wisata mampu meningkatkan pendapatan masyarakat sekitar desa wisata, berkontribusi positif terhadap peningkatan kesempatan kerja, mengurangi pengangguran di masyarakat desa, serta menjadi faktor pemicu terhadap pengembangan infrastruktur pendukung. Oleh sebab itu, hal tersebut pemicu untuk setiap desa mengembangkan desa wisata. Meskipun dana desa dapat digunakan untuk pembangunan sektor pariwisata di desa, alokasi dana desa untuk sektor wisata tidak bisa mudah diusulkan. Rancangan penggunaan dana desa harus melalui musyawarah desa agar seluruh kelompok terakomodasi. Proses pengembangan desa wisata dengan pendanaan dari dana desa membutuhkan proses yang tidak sebentar, memakan waktu. Selain itu, kemungkinan besarnya dana alokasi dari dana desa untuk sektor wisata kemungkinan tidak sesuai harapan menimbang banyaknya program desa yang juga memerlukan pendanaan dari dana desa. Oleh karena itu, pendanaan mandiri di luar dari dana desa perlu dicari dan diupayakan untuk mewujudkan desa wisata sesuai harapan masyarakat desa.

Mengapa UMKM wajib ditumbuhkembangkan di Indonesia. Kuncoro (2014) mengidentifikasi tiga alasan. Pertama, UMKM menyerap banyak tenaga kerja. Kecenderungan menyerap banyak tenaga kerja umumnya membuat banyak UMKM juga intensif dalam menggunakan sumber daya alam lokal. Apalagi karena lokasinya banyak di pedesaan, pertumbuhan UMKM akan menimbulkan dampak positif terhadap peningkatan jumlah tenaga kerja, pengurangan jumlah kemiskinan, pemerataan dalam distribusi pendapatan, dan pembangunan ekonomi di pedesaan (Kuncoro, 1996; Simatupang, Togatorop, \& Sitompul, 1994). Kedua, UMKM memegang peranan penting dalam ekspor nonmigas yang pada tahun 1990 mencapai US\$ 1.031 juta atau menempati rangking kedua setelah ekspor dari kelompok aneka industri. UMKM (Usaha Kecil \& Menengah) juga berkontribusi terhadap penerimaan ekspor, tetapi kontribusi UMKM jauh lebih kecil dibandingkan dengan kontribusi usaha besar. Pada UMKM, penyumbang terbesar ekspor nonmigas juga sektor industri pengolahan, terutama garmen, tekstil, dan produk tekstil, dan sepatu. Ketiga, adanya urgensi untuk struktur ekonomi yang berbentuk piramida pada PJPT I menjadi semacam "gunungan" pada PJPT II. Pada dasarnya, piramida didominasi oleh usaha skala menengah dan kecil yang beroperasi dalam iklim yang sangat kompetitif, hambatan masuk rendah, margin keuntungan rendah, dan tingkat drop-out tinggi. Struktur ekonomi bentuk piramida terbukti telah mencuatkan isu konentrasi dan konglomerasi, serta banyak dituding melestarikan dualisme perekonomian nasional. UMKM merupakan perwujudan konkret dari kegiatan ekonomi rakyat yang bertumpu pada kekuatan sendiri, terdesentralisasi, beragam, dan merupakan kelompok usaha yang mampu menjadi "buffer" saat perekonomian Indonesia dilanda krisis. Keragaman UMK seperti petani kecil atau petani gurem, petani tanpa lahan, nelayan kecil, pedagang kecil, industri rumah 
tangga, dan sebagainya adalah pelaku ekonomi yang memberi andil cukup besar dalam perekonomian nasional. Fungsi dan peranan UMK sangat penting tidak hanya sebagai sumber mata pencaharian orang banyak tetapi juga menyediakan secara langsung lapangan kerja bagi masyarakat yang tingkat pengetahuan dan keterampilannya rendah. Populasi UMK sangat besar dan jenis usahanya meliputi berbagai sektor. Sebagian besar bergerak disektor informal yang banyak menyerap tenaga kerja. Namun, ternyata keberadaannya kurang mendapatkan dukungan dari sektor perbankan. Hal ini terbukti pada informasi yang diperoleh dari:

1. Data Kementrian Departemen Koperasi dan Usaha Mikro dan Kecil tahun 2004 menyebutkan bahwa kelompok usaha mikro nasional sebanyak 41.800 .000 unit $(98,5 \%)$ dari total unit usaha nasional sebanyak 42.452.000 unit.

2. Noer Soetrisno (2003) mengatakan akses usaha mikro, termasuk usaha mikro agrobisnis, terhadap lembaga keuangan formal terutama bank sangat rendah yaitu hanya sekitar $12 \%$.

3. Sri Hartati Samhadi (2006) dan Didik J. Rachbini (2006) menyebutkan bahwa usaha mikro pada umumnya bergerak disektor informal.

4. Biro Pusat Statistik (BPS, 2015) menyebutkan bahwa sektor informal yang diwakili oleh usaha mikro menyerap lebih dari $70 \%$ dari angkatan kerja, sedangkan sektor formal hanya menyerap 30\% dari angkatan kerja.

Secara legal setiap usaha yang ada di berbagai sektor ekonomi menurut pengertian UU No.9/1995 (Kementerian Keuangan, 1995) dapat dikategorikan sebagai usaha kecil sepanjang omzetnya berada di bawah Rp1 miliar, memiliki aset kurang dari Rp200 juta di luar tanah dan bangunan, dan bukan merupakan anak perusahaan dari usaha besar. Cakupan yang luas dan melebar memang menyebabkan fokus pengembangan sering tidak efektif karena karakter dan orientasi bisnis yang dijalankan oleh para pemilik usaha, jika digunakan basis penyediaan pembiayaan sebagai pengolah pakar, usaha kecil dalam pengertian UU No. 9/1995 dapat dibedakan menjadi tiga kelompok:

1. Kelompok usaha mikro dengan omset di bawah Rp50 juta yang diperkirakan merupakan 97\% dari seluruh populasi usaha kecil.

2. Kelompok usaha kecil dengan omset antara Rp50 juta - Rp500 juta yang jumlahnya relatif kecil hanya sekitar $2 \%$ dari seluruh populasi usaha kecil.

3. Kelompok usaha kecil menengah mungkin dapat kita sebut usaha mikro yang memiliki omset antara Rp500 juta - Rp1 miliar dan relatif sangat kecil jumlahnya, yaitu kurang dari $1 \%$ atau tepatnya sekitar $0,5 \%$ saja.

Desa Triharjo di Kecamatan Pandak adalah desa yang memiliki sumber daya alam di bidang pariwisata, yaitu Kedung Ngancar. Wisata Kedung Ngancar merupakan wahana wisata air yang dikelilingi Sungai Progo, Sungai Bedog, dan saluran dari Dam Kamijoro yang dilengkapi dengan perahu-perahu yang akan menyusuri sungai Bedog dan saluran dari dam Kamijoro. Sayangnya, wisata air tersebut hanya dijual apa adanya, tanpa ada upaya untuk meningkatkan nilai jual. Wisata Kedung Ngancar melibatkan semua pihak mulai dari aparat desa dan karang taruna yang tergabung dalam Pokdarwis. Hal ini dilakukan dengan harapan agar seluruh masyarakat ikut berpartisipasi membangun wisata rakyat yang menguntungkan bagi semua pihak. Meskipun seluruh elemen masyarakat telah berpartisipasi, jika pengelolaannya masih sederhana, hasilnya tidak optimal. Untuk dapat menjaga kesinambungan pelayanan pariwisata yang berkualitas, pengelola wisata desa harus dapat menyajikan potensi keunggulan wisata desa yang ada, sarana prasarana, manajemen pengelolaan yang baik, cara mendapatkan dana, mengelola, melaporkan dan mengawasinya. Untuk dapat mewujudkan desa wisata yang memadai, faktor pendanaan menjadi masalah utama masyarakat desa. Terbatasnya akses ke lembaga keuangan, tidak adanya jaminan, dan minimnya pengetahuan tentang pengelolaan keuangan membuat institusi/lembaga keuangan (bank dan sejenisnya) bersikap hati-hati (enggan) memberikan pinjaman. 
Belum adanya pengetahuan tentang cara mendapatkan pendanaan (investasi) di bidang pariwisata dan tidak adanya pendampingan dari pihak-pihak yang kompeten menjadi faktor lain yang memengaruhi belum adanya keinginan dari Pokdarwis menyusun proposal bisnis untuk pengembangan wisata Kedung Ngancar dengan optimal. Dari hasil survei lapangan Susyanti dan Latianingsih (2014) ke beberapa desa wisata, dapat diketahui bahwa masyarakat desa belum memiliki pengetahuan dan keterampilan yang memadai dalam mengelola desa wisata, padahal pengetahuan tentang pengelolaan desa wisata merupakan suatu keterampilan yang sebenarnya dibutuhkan oleh masyarakat desa wisata, baik yang sudah ada ataupun bagi masyarakat yang ingin mengembangkan desanya menjadi sebuah desa wisata. Sosialisasi, pelatihan, dan pendampingan yang cukup dibutuhkan bagi para pemuda agar mereka dapat memiliki pengetahuan dan keterampilan pengelolaan desa wisata. Oleh karena itu, perlu diberikan pelatihan menyusun proposal bisnis yang menarik investor untuk mengembangkan usaha pariwisata pada Pokdarwis Taman Wisata Kedung Ngancar (TWK). Proposal yang berhasil menarik investor untuk menanamkan modalnya ke TWK diharapkan dapat meningkatkan perekonomian masyarakat, khususnya warga di Desa Triharjo. Berdasarkan permasalahan tersebut, pelatihan penyusunan proposal bisnis untuk mengembangkan industri pariwisata bagi pemuda yang tergabung dalam kelompok sadar wisata (Pokdarwis) di Desa Triharjo, Pandak, Bantul sangat diperlukan sehingga dapat meningkatkan pendapatan bagi masyarakat sekitar dan desa. Selain itu, pembuatan rencana usaha kreatif diharapkan dapat membangun usaha-usaha kreatif anggota Pokdarwis TWK guna meningkatkan ekonomi daerah serta mempersiapkan diri untuk menghadapi persaingan global melalui ekonomi kreatif. Hermawan (2016) menyatakan bahwa dengan adanya pengembangan desa wisata, akan meningkatkan penghasilan masyarakat, peluang kerja dan usaha, kepemilikan dan kontrol masyarakat lokal, pendapatan pemerintah melalui retribusi wisata.

\section{Metode Pelaksanaan}

Pokdarwis TWK terpilih sebagai khalayak sasaran kegiatan pelaksanaan kegiatan pengabdian pada masyarakat, yakni pelatihan penyusunan proposal bisnis berdasarkan hasil observasi tim pengabdi. Di antara beberapa Pokdarwis di wilayah Bantul, Pokdarwis TWK sudah memiliki konsep pengembangan taman wisata yang jelas, yaitu wisata air dan edukasi pembuatan tempe dan emping. Hal ini berarti menggabungkan potensi alam dan potensi sumber daya masyarakat sekitar. Selain itu, Pokdarwis TWK juga memiliki modal awal pengembangan taman wisata, berupa aset atau infrastruktur yang memadai, seperti joglo, beberapa gazebo, dan spot untuk swafoto. Namun, untuk sarana, prasarana, dan wahana belum lengkap. Calon investor lebih menyukai investee yang sudah memiliki konsep dan modal yang jelas. Investor akan menghindari menanamkan dananya pada usaha yang berisiko tinggi, tidak terkonsep jelas arahnya. Pokdarwis TWK telah memiliki modal dan konsep pengembangan yang jelas, tetapi belum tahu cara menarik investor. Dengan demikian, pemilihan Pokdarwis TWK sebagai khlayak sasaran dinilai tepat. Podarwis TWK memerlukan pelatihan proposal bisnis untuk menarik investor berperan serta mengembangkan TWK.

Peningkatan kapasitas UMKM melalui pelatihan penyusunan proposal bisnis ini dilakukan dengan menggunakan metoda ceramah, tutorial, diskusi, pendampingan. Adapun sistematika pelaksanaan kegiatan pengabdian ini adalah sebagai berikut: Langkah pertama metoda ceramah. Peserta diberikan pengetahuan tentang pentingnya akses pendanaan dan alternatif pendanaan lainnya untuk mendukung pengembangan Desa Wisata. Pada langkah ini waktu penyelenggaraan selama 2 jam. Selanjutnya, langkah kedua metoda tutorial. Peserta pelatihan diberikan dua materi, yakni tentang pentingnya menyusun proposal bisnis yang menarik investor dan kedua penyusunan proposal bisnis untuk pengembangan Desa Wisata. Langkah kedua diselenggarakan selama 6 jam. Langkah ketiga metoda diskusi. Peserta pelatihan diberikan 
kesempatan untuk mendiskusikan permasalahan yang berkaitan dengan pembuatan proposal pendanaan desa wisata yang dihadapi oleh peserta sehingga peserta mampu membuat proposal pendanaan desa wisata yang baik. Langkah ketiga diselenggarakan selama 4 jam. Terakhir, langkah keempat pendampingan. Pada langkah ini, tim pengabdi akan memberikan pendampingan kepada Pokdarwis secara berkala. Langkah keempat diselenggarakan selama minimal 4 jam. Semua kegiatan pelatihan dilakukan di Joglo TWK.

Untuk menganalisis hasil keberhasilan kegiatan ini, khalayak sasaran Pokdarwis TWK diberi angket penilaian kegiatan pelatihan penyusunan proposal bisnis. Angket tersebut berisi penilaian tentang: pelaksanaan kegiatan, penyampaian materi oleh nasrasumber, kejelasan materi, pelayanan tim pengabdi selama pelatihan, kepuasan peserta pelatihan, manfaat pelatihan, dan tindak lanjut. Angket tersebut juga menjaring aspirasi harapan Pokdarwis TWK di masa yang akan datang terkait dengan pengembangan TWK dan kesediaan bilamana ada kegiatan pelatihan lanjutan. Data dari angket tersebut selanjutnya dianalisis dengan deskriptif kuantitatif untuk mengetahui nilai kegiatan pelatihan penyusunan proposal bisnis dalam bentuk gambar dan tabel.

\section{Hasil dan Pembahasan}

\section{Hasil Perencanaan}

Pada tahap perencanaan ini, tim pengabdi mengadakan koordinasi awal dengan tim Pokdarwis Taman Wisata Kedung Ngancar, Desa Triharjo, Kecamatan Pandak, Kabupaten Bantul. Koordinasi awal dilakukan sebanyak dua kali pertemuan. Pertemuan pertama dilakukan di Desa Triharjo dengan agenda pertemuan mendiskusikan materi yang akan disampaikan dalam kegiatan pengabdian masyarakat. Agenda ini dimulai dengan diskusi awal mengenai kondisi UMKM di Pokdarwis Taman Wisata Kedung Ngancar saat ini serta kebutuhan pengembangan sarana prasarana UMKM di Pokdarwis Taman Wisata Kedung Ngancar. Dalam pembicaraan tersebut, dapat disimpulkan bahwa dalam proses pengembangan bisnisnya, UMKM di Pokdarwis Taman Wisata Kedung Ngancar mengalami kesulitan untuk akses modal dan pengembangan bisnis. Oleh karena itu, dalam tahap perencanaan ini disepakati bahwa tim pengabdi akan menyampaikan materi mengenai peningkatan kapasitas UMKM melalui pelatihan penyusunan proposal bisnis untuk membantu para anggota UMKM di Pokdarwis Taman Wisata Kedung Ngancar dalam mengakses dana dan mengembangkan bisnisnya. Setelah materi disetujui, diskusi dilanjutkan dengan penjadwalan waktu pelatihan tersebut akan dilaksanakan.

Selepas pertemuan pertama, kembali diselenggarakan pertemuan kedua dengan agenda pematangan perencanaan pelaksanaan pelatihan. Dalam pertemuan kedua ini, tim dari UNY dan Pokdarwis Taman Wisata Kedung Ngancar berdiskusi secara daring (online) karena pandemi Covid-19 yang semakin naik. Tim dari Pokdarwis Taman Wisata Kedung Ngancar menyusun daftar pembagian tugas persiapan dan pelatihan penyusunan proposal bisnis dengan tim pengabdi. Waktu dan lokasi pelatihan ditentukan pada bulan September 2020 di Pendopo Taman Wisata Kedung Ngancar. Pelaksanaan pelatihan ini agak mundur dari waktu yang telah disepakati pada pertemuan pertama karena menunggu kondisi pandemi Covid-19 lebih kondusif.

\section{Pelaksanaan}

Pelaksanaan kegiatan pengabdian masyarakat peningkatan kapasitas UMKM melalui pelatihan penyusunan proposal bisnis bertujuan agar UMKM yang tergabung dalam Pokdarwis Taman Wisata Kedung Ngancar di Bantul dapat mudah memperoleh akses pendanaan dari investor. Pelatihan ini dihadiri oleh 26 peserta yang terdiri atas anggota UMKM Pokdarwis Taman Wisata Kedung Ngancar, Desa Triharjo, Kecamatan Pandak, Kabupaten Bantul . Susunan acara pelatihan sebagai berikut : 
Tabel 1. Kegiatan “Peningkatan Kapasitan UMKM melalui Pelatihan Penyusunan Business Plan” untuk Memperoleh Pendanaan dan Pengembangan Desa Wisata.

\begin{tabular}{|c|l|}
\hline \multicolumn{1}{|c|}{ Sesi } & \multicolumn{1}{c|}{ Materi } \\
\hline 1 & Pendahuluan tentang Potensi Desa Wisata \\
\hline 2 & $\begin{array}{l}\text { Alternatif Pendanaan untuk Pengembangan Desa Wisata dan Mekanisme Akses } \\
\text { Pengajuan Pendanaan }\end{array}$ \\
\hline 3 & $\begin{array}{l}\text { Penyusunan Proposal Pengajuan Pendanaan untuk Pengembangan Desa Wisata: } \\
\text { Pendahuluan (Analisis Pasar dan Pesaing) }\end{array}$ \\
\hline 4 & $\begin{array}{l}\text { Penyusunan Proposal Pengajuan Pendanaan untuk Pengembangan Desa Wisata: } \\
\text { Aspek Pemasaran dan Organisasi }\end{array}$ \\
\hline 5 & $\begin{array}{l}\text { Penyusunan Proposal Pengajuan Pendanaan untuk Pengembangan Desa Wisata: } \\
\text { Aspek Produksi }\end{array}$ \\
\hline 6 & $\begin{array}{l}\text { Penyusunan Proposal Pengajuan Pendanaan untuk Pengembangan Desa Wisata: } \\
\text { Aspek Keuangan }\end{array}$ \\
\hline $\begin{array}{l}\text { Daring } \\
\text { Pendampingan }\end{array}$ & Reviu Proposal dan Tanya Jawab \\
\hline
\end{tabular}

\section{Pendampingan}

Pendampingan dilakukan dengan sistem online untuk membantu para peserta pelatihan lebih memahami cara memperoleh pendanaan dan cara melakukan penyusunan proposal bisnis desa wisata. Komunikasi dilakukan baik menggunakan email maupun whatssapp group. Untuk menunjang proses pendampingan, materi utama dan tambahan yang diperlukan juga dibagikan Tim Pengabdi melalui link dropbox agar semua peserta pelatihan dapat mengakses informasi tersebut secara bebas.

\section{Pembahasan}

Pelaksanaan peningkatan kapasitas UMKM melalui pelatihan penyusunan Business Plan untuk pengembangan Taman Wisata Kedung Ngancar, Desa Triharjo, Kecamatan Pandak, Kabupaten Bantul dihadiri oleh 25 peserta yang terdiri atas pihak Pokdarwis Taman Wisata Kedung Ngancar dan tim pengabdi. Materi pertama mengenai penjelasan awal tentang potensi desa wisata. Isi materi ini menjelaskan potensi desa wisata. Tren wisata sekarang adalah wisata yang menghargai lngkungan, alam, budaya, dan atraksi secara spesial. Produk wisata konvensional mulai ditinggalkan (Susyanti \& Latianingsih, 2014). Implikasi atas pergeseran minat wisatawan tersebut ialah bahwa di Indonesia pun tumbuh pilihan wisata baru berupa desa wisata di berbagai provinsi di Indonesia. Keberadaan desa wisata ini diharapkan dapat menanggulangi kemiskinan. Untuk itu diperlukan kesiapan dari seluruh warga masyarakat untuk membuka diri dan berubah. Warga masyarakat sebagai bagian dari stakeholder memiliki peran penting dalam mengembangkan sebuah daya tarik desa wisata (Sunarjaya, Antara, \& Prasiasa, 2018).

Materi kedua tentang alternatif pendanaan untuk pengembangan desa wisata dan mekanisme akses pengajuan pendanaan. Sesi kedua ini menjelaskan kondisi umum pendanaan desa wisata yang ada selama ini. Pada umumnya, pendanaan desa wisata dari pemerintah sangat terbatas (Sunarjaya et al., 2018). Meskipun pemerintah telah berupaya memberikan bantuan pendanaan melalui beberapa kementerian (Kemenparekraf, Kemensos, Kemenkop dan UMKM), belum semua desa wisata mendapat bantuan. Masyarakat juga belum terlibat penuh dalam perencanaan dan pengembangan. Hal ini disebabkan masyarakat belum memiliki pengalaman dan keahlian, terutama dalam menarik calon investor. Oleh karena itu, pada sesi kedua ini, tim pengabdi menjelaskan secara rinci berbagai sumber alternatif pendanaan di luar pemerintah yang dapat diakses oleh Pokdarwis, seperti Kredit Usaha Rakyat (KUR) yang dikeluarkan oleh beberapa bank atau alternatif lainnya seperti crowdfunding. Crowdfunding adalah jenis penggalangan dana untuk proyek-proyek kreatif, tetapi juga untuk perusahaan. Hal yang menarik lainnya adalah crowdfunding bersifat terbuka, menggunakan metode web 2.0 untuk komunikasi dan biasanya memiliki jenis materi atau imbalan yang nonmateri. Bouncken (2015) 
menyatakan crowdfunding berfokus pada penggalangan dana keuangan dari publik dan diwakili oleh sekelompok orang dengan menggunakan platform berbasis internet tertentu. Artinya, crowdfunding adalah penggalangan dana yang bersifat terbuka dari banyak individu untuk membiayai proyek-proyek yang inovatif atau memiliki tujuan tertentu dengan memanfaatkan internet melalui sebuah platform yang akan memberikan pengembalian kepada pemberi dana berupa moneter ataupun nonmoneter.

Materi ketiga hingga keenam berisi tentang penyusunan proposal pengajuan pendanaan untuk pengembangan desa wisata di Kedung Ngancar, khususnya topik analisis pasar dan pesaing, aspek pemasaran dan organisasi, aspek produksi dana aspek keuangan. Materi ketiga ini merupakan materi inti yang dibagi dalam tiga sesi. Isi materi ini membahas cara menyusun proposal yang ideal. Proposal yang ideal minimal mencakup pendahuluan, rangkuman eksekutif, analisis industri (meliputi analisis pasar, analisis pesaing), rencana usaha dan risiko, perencanan permodalan, analisis kelayakan usaha, dan penutup. Proposal bisnis ini yang dibuat dapat bervariasi tergantung pada situasi tertentu. Sebagai contoh, proposal bisnis dapat fokus pada uraian tentang deskripsi dari tim manajemen karena informasi deskripsi dari tim manajemen sangat penting bagi investor. Sementara proposal bisnis lain lebih fokus pada sejarah keuangan karena informasi tersebut dinilai paling penting bagi bank.

Pada akhir pelatihan hari kedua peserta diberi kuesioner yang bertujuan untuk melihat apakah tujuan pengabdian telah tercapai. Apabila dirasa belum tercapai dan peserta belum mendapatkan manfaat dari pengabdian, perlu dilakukan langkah evaluasi. Setelah materi disampaikan, peserta mulai menyusun proposal bisnis dengan didampingi oleh tim pengabdi. Komunikasi penyusunan proposal dilakukan melalui daring (meet, zoom, wa group, dll). Proposal yang dibuat selanjutnya direview oleh tim pengabdi. Hasil review dari tim pengabdi menjadi masukan perbaikan proposal hingga proposal siap untuk diserahkan ke penyandang dana (calon investor).

\section{Evaluasi Kegiatan}

Evaluasi kegiatan pengabdian dilaksanakan setelah materi selesai dilakukan dengan cara memberikan angket evaluasi pengabdian untuk diisi peserta pelatihan. Beberapa indikator yang dievaluasi dalam angket adalah sebagai berikut:

\section{Pelaksanaan Kegiatan Pelatihan}

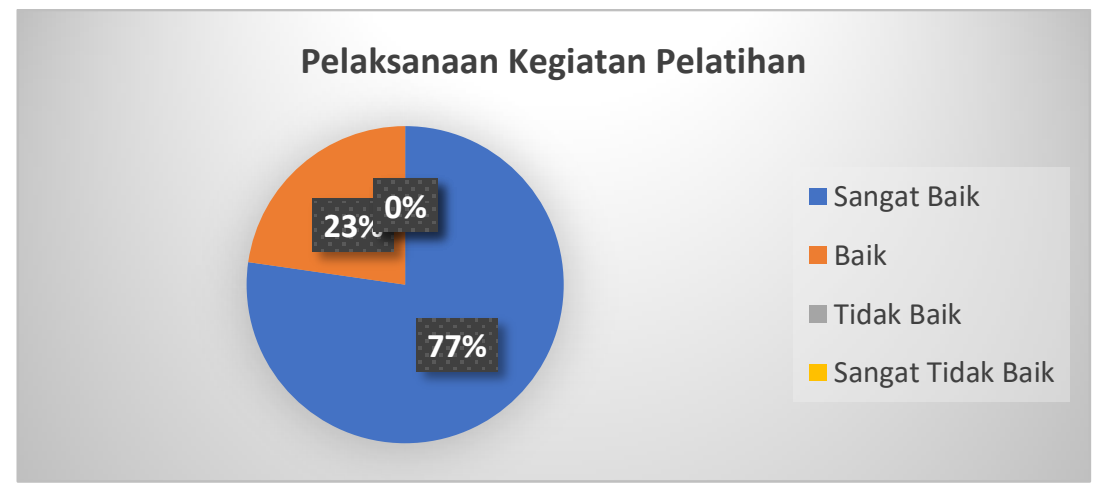

Gambar 1. Hasil Evaluasi Pelaksanaan Kegiatan Pelatihan

Hasil evaluasi peserta terkait dengan pelaksanaan kegiatan pelatihan menunjukkan bahwa pelaksanaan kegiatan perlatihan sudah berjalan dengan baik. Hal ini dapat ditunjukkan bahwa dari hasil evaluasi, terdapat $77 \%$ peserta pelatihan yang menyatakan sangat baik, dan $23 \%$ peserta pelatihan menyatakan bahwa pelaksanaan kegiatan pelatihan berjalan dengan baik. Tidak ada satu pun peserta yang menyatakan tidak baik atau sangat tidak baik. 
2. Kejelasan Penyampaian Materi Proposal Pengajuan Dana untuk Pengembangan Desa Wisata: Pendahuluan (Analisis Pasar dan Pesaing) yang Disampaikan Narasumber

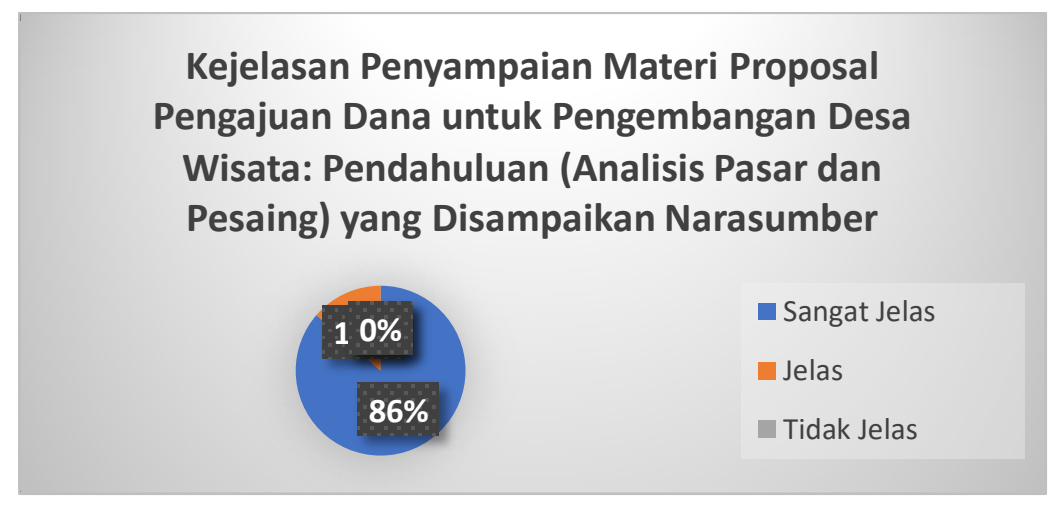

Gambar 2. Hasil Evaluasi Kejelasan Penyampaian Materi Proposal Pengajuan Dana untuk Pengembangan Desa Wisata: Pendahuluan (Analisis Pasar dan Pesaing)

Berdasarkan pada Gambar 2, diketahui hasil evaluasi tentang penyampaian materi proposal pengajuan dana untuk pengembangan desa wisata, yakni pendahuluan (khususnya analisis pasar dan pesaing) menunjukkan bahwa terdapat $86 \%$ peserta pelatihan yang menyatakan sangat jelas, dan $14 \%$ peserta pelatihan menyatakan jelas. Tidak ada satu pun peserta pelatihan yang menyatakan tidak jelas ataupun sangat tidak jelas.

3. Kejelasan Penyampaian Materi Proposal Pengajuan Dana untuk Pengembangan Desa Wisata: Aspek Pemasaran dan Organisasi yang Disampaikan Narasumber

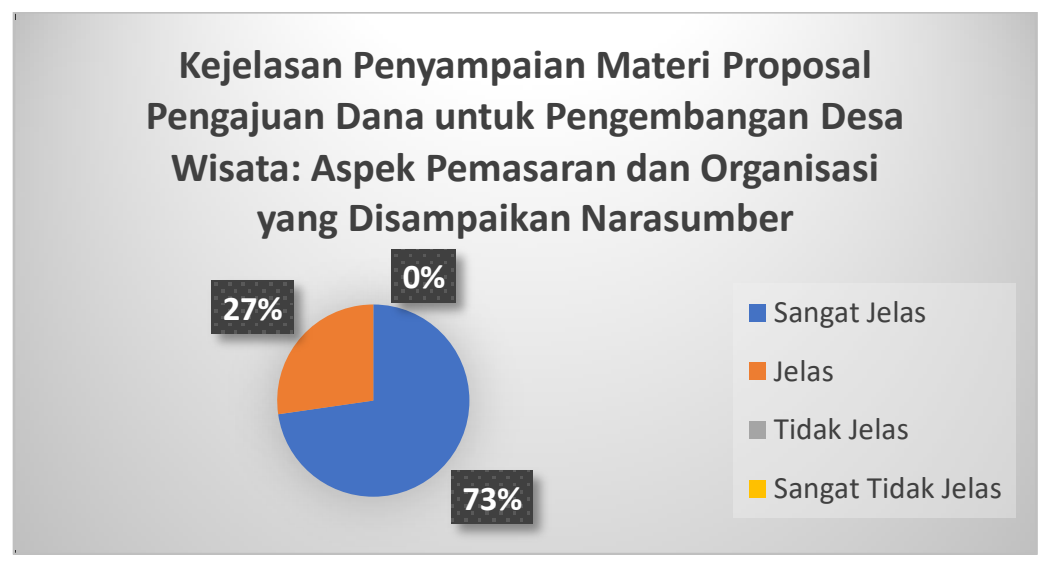

Gambar 3. Hasil Evaluasi Kejelasan Penyampaian Materi Proposal Pengajuan Dana untuk Pengembangan Desa Wisata: Aspek Pemasaran dan Organisasi

Hasil evaluasi yang diberikan peserta untuk indikator kejelasan penyampaian materi proposal pengajuan dana untuk pengembangan desa wisata, yaitu aspek pemasaran dan organisasi menunjukkan sebanyak $73 \%$ peserta menyatakan sangat jelas, $27 \%$ menyatakan jelas. Untuk indikator ini tidak ada satu pun peserta yang menyatakan tidak jelas dan sangat tidak jelas. 
4. Kejelasan Penyampaian Materi Proposal Pengajuan Dana untuk Pengembangan Desa Wisata: Aspek Produksi dan Keuangan yang Disampaikan Narasumber

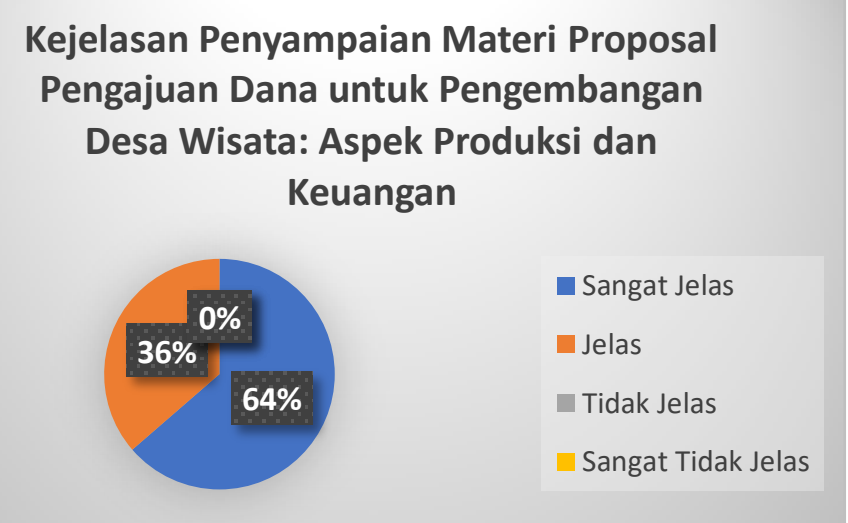

Gambar 4. Hasil Evaluasi Kejelasan Penyampaian Materi Proposal Pengajuan Dana untuk Pengembangan Desa Wisata: Aspek Produksi dan Keuangan

Berdasarkan pada Gambar 4, diketahui hasil evaluasi tentang penyampaian materi proposal pengajuan dana untuk pengembangan desa wisata yakni aspek produksi dan keuangan yang disampaikan oleh narasumber menunjukkan terdapat $64 \%$ peserta pelatihan yang menyatakan sangat jelas dan 36\% peserta pelatihan menyatakan jelas. Tidak ada satu pun peserta pelatihan yang menyatakan tidak jelas ataupun sangat tidak jelas.

\section{Kualitas Pelayanan Selama Pelatihan}

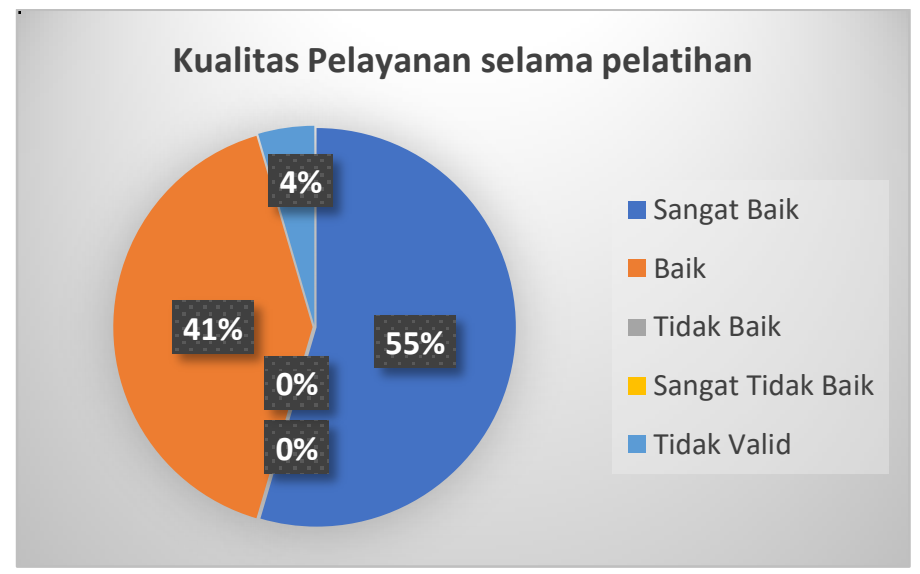

Gambar 5. Hasil Evaluasi Kualitas Pelayanan Selama Pelatihan

Hasil evaluasi yang diberikan peserta untuk indikator kualitas pelayanan selama pelatihan menunjukkan bahwa 55\% peserta pelatihan menyatakan sangat baik, $41 \%$ peserta menyatakan baik. Tidak ada satu pun peserta yang menyatakan tidak baik dan sangat tidak baik pada indikator ini. Pada indikator ini, terdapat $4 \%$ (1 orang) yang tidak mengisikan respon pada angket sehingga dianggap tidak valid.

6. Kemampuan Personil PPM dalam Memberikan Layanan 


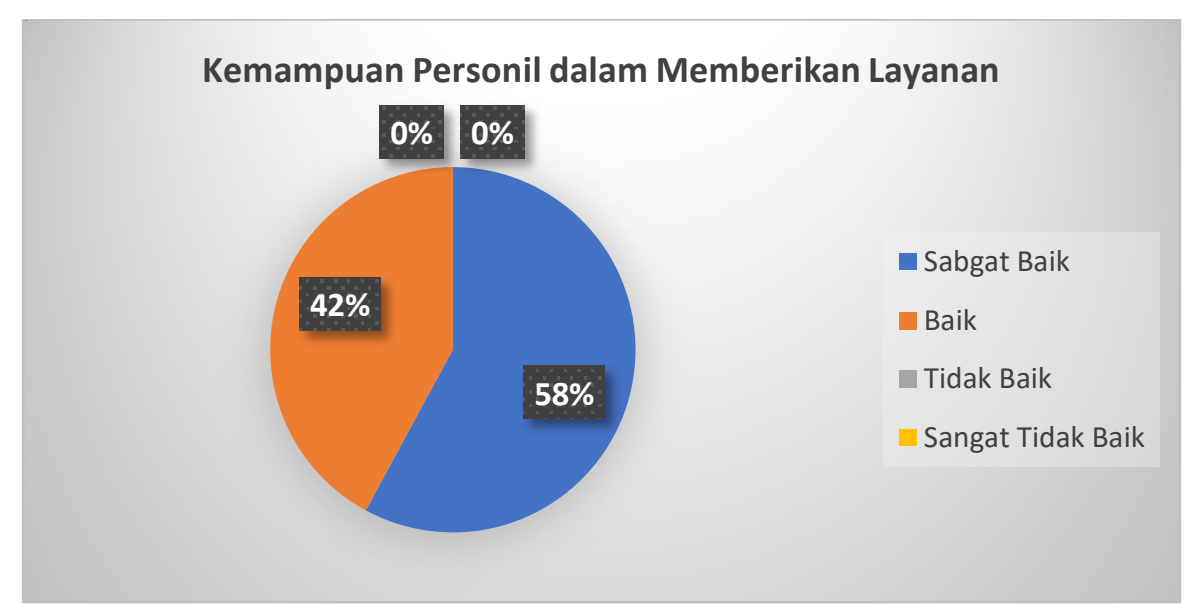

Gambar 6. Kemampuan Personil dalam Memberikan Layanan

Hasil evaluasi yang diberikan peserta untuk indikator kemampuan personil PPM dalam memberikan layanan selama pelatihan berlangsung menunjukkan $42 \%$ dari seluruh peserta menyetujui bahwa seluruh personil PPM mampu memberikan layanan yang baik dan 58\% menyatakan sangat baik.

7. Kepuasan Peserta Terhadap Kegiatan Peningkatan Kapasitas UMKM melalui Pelatihan Penyusunan Business Plan

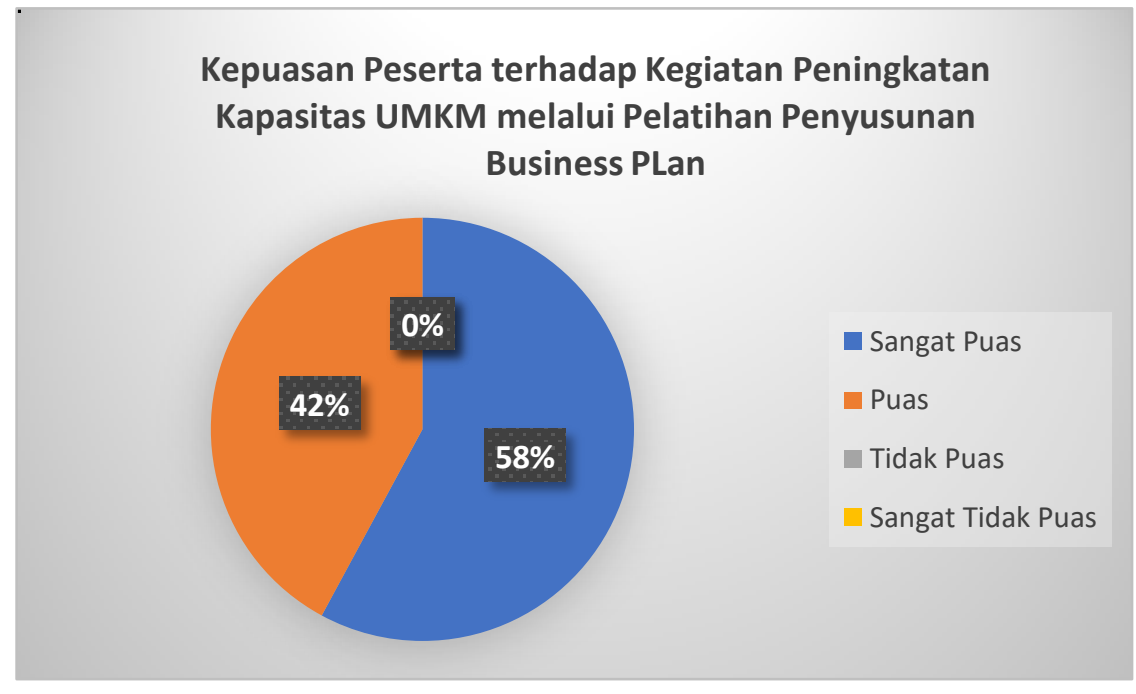

Gambar 7. Kepuasan Peserta terhadap Penyelenggaraan Pelatihan

Hasil evaluasi berikut ini menunjukkan kepuasan peserta terhadap penyelenggaraan peningakatan kapasitas UMKM melalui pelatihan penyusunan Business Plan._Berdasarkan hasil evaluasi, $58 \%$ peserta latihan menyatakan sangat puas dan $42 \%$ menyatakan puas terhadap pelatihan yang diselenggarakan oleh kelompok PPM dosen FE UNY.

\section{Kesesuaian Penyelenggaraan Pelatihan dengan Harapan Peserta}




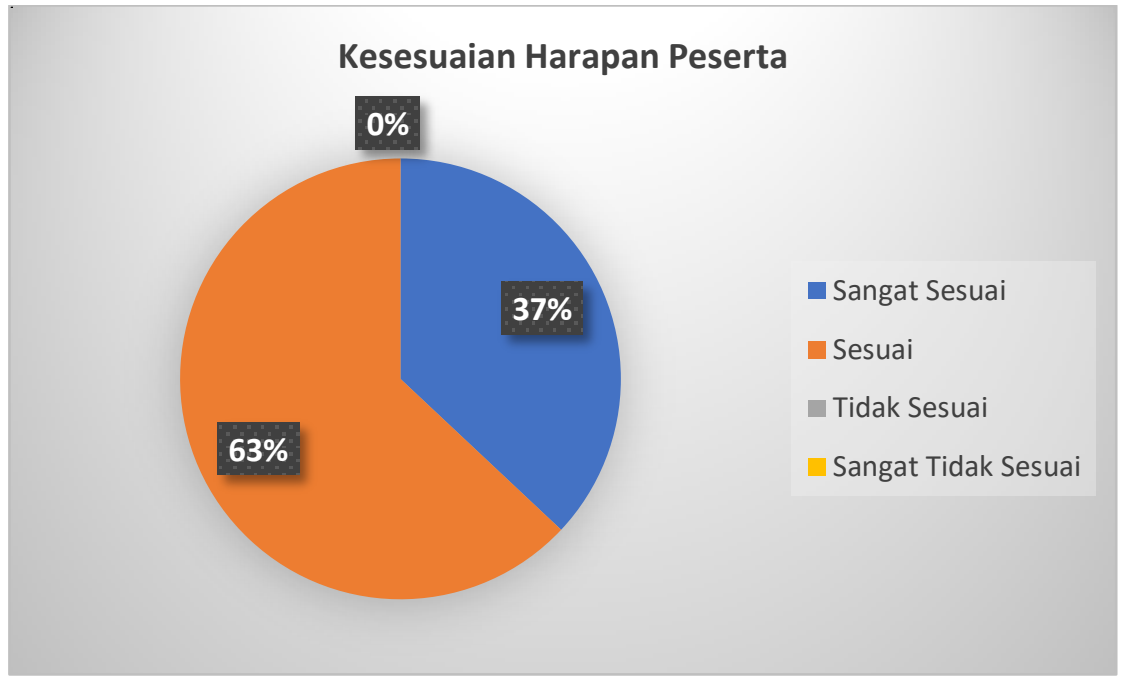

Gambar 8. Hasil Evaluasi Kesesuaian Harapan Peserta terhadap Pelatihan

Hasil evaluasi yang diberikan peserta untuk indikator kesesuaian harapan peserta terhadap penyelenggaraan pelatihan menunjukkan sebanyak $37 \%$ peserta menyatakan sangat sesuai, 63\% menyatakan sesuai, dan tidak satu pun perserta menyatakan tidak sesuai. Untuk indikator ini, tidak ada satu pun peserta yang menyatakan sangat tidak sesuai.

\section{Manfaat Pelatihan}

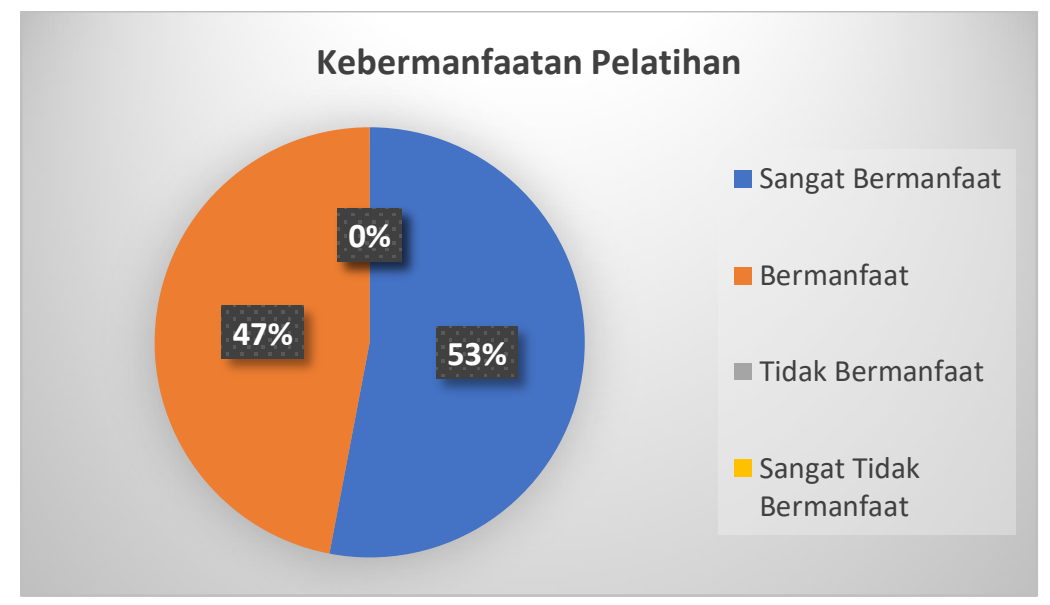

Gambar 9. Hasil Evaluasi Manfaat Pelatihan

Hasil evaluasi yang diberikan peserta untuk indikator kesesuaian harapan peserta terhadap penyelenggaraan pelatihan diketahui sebanyak $53 \%$ peserta menyatakan sangat bermanfaat dan $47 \%$ menyatakan bermanfaat. Untuk indikator ini, tidak ada satu pun peserta yang menyatakan tidak bermanfaat dan sangat tidak bermanfaat.

\section{Tindak Lanjut terhadap Pertanyaan dan Keluhan}




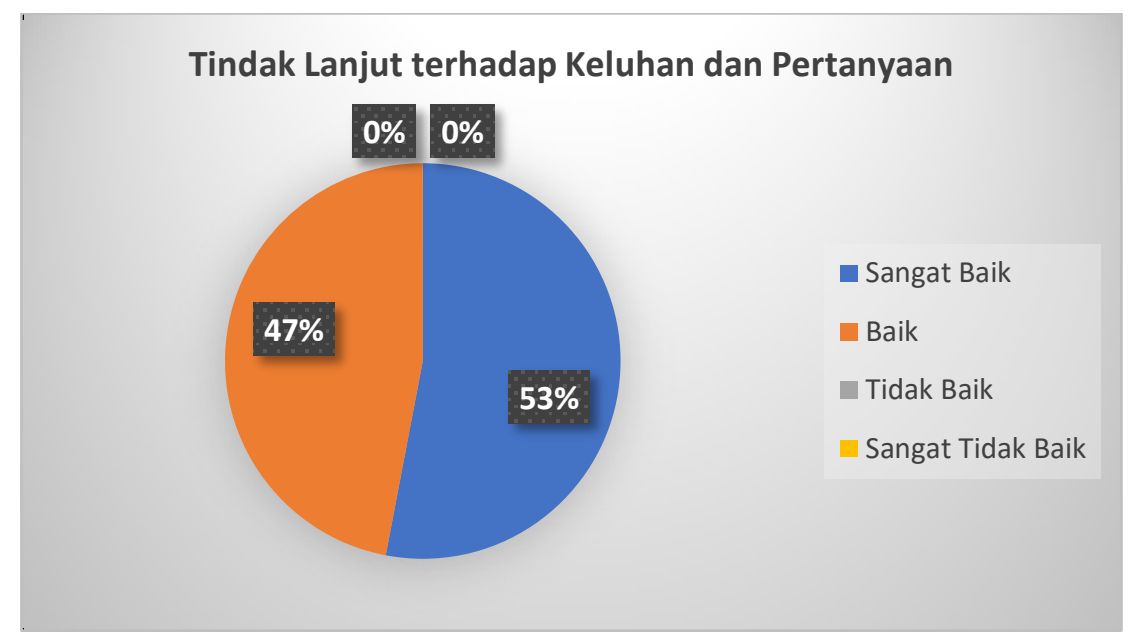

Gambar 10. Hasil Evaluasi Tindak Lanjut terhadap Pertanyaan dan Keluhan

Hasil evaluasi yang diberikan peserta untuk indikator tindak lanjut terhadap pertanyaan dan keluhan yang diajukan peserta pelatihan kepada para pemateri, terlihat sebanyak 53\% peserta menyatakan sangat baik dan $47 \%$ menyatakan baik. Untuk indikator ini tidak ada satu pun peserta yang menyatakan tidak baik dan sangat tidak baik.

11. Kesediaan untuk Berpartisipasi Kembali Pada Training di Masa Mendatang

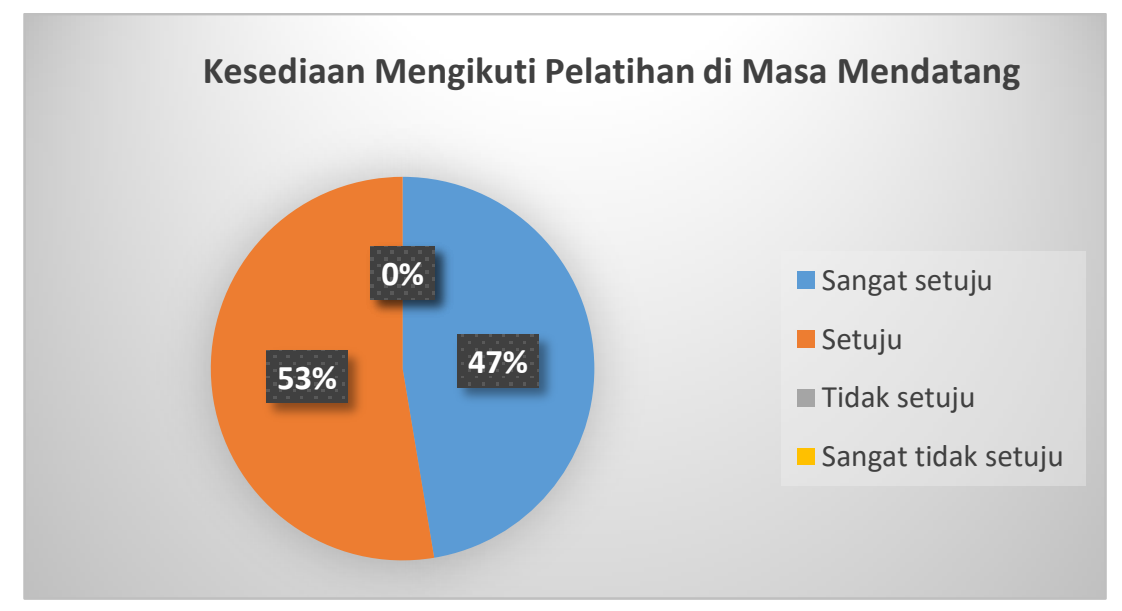

Gambar 11. Hasil Evaluasi Kesediaan Mengikuti Training di Masa Mendatang

Hasil evaluasi yang diberikan peserta untuk indikator kesesuaian harapan peserta terhadap penyelenggaraan pelatihan yakni sebanyak $47 \%$ peserta menyatakan sangat setuju dan $53 \%$ menyatakan setuju. Untuk indikator ini tidak ada satupun peserta yang menyatakan tidak setuju dan sangat tidak setuju.

Dari hasil angket evaluasi pelaksanaan, secara umum pelaksanaan pengabdian dapat dikategorikan terlaksana dengan baik. Hal ini dapat dilihat dari angket evaluasi yang disebarkan mayoritas peserta pengabdian memberikan skor 3 dan 4 pada ke sebelas indikator. Hal ini dapat diartikan bahwa peserta menyatakan setuju dan sangat setuju terhadap pelaksanaan pelatihan ini. Kejelasan materi, kepuasan terhadap pelatihan, manfaat pelatihan, kesesuaian harapan dengan penyelenggaraan pelatihan, serta keinginan untuk mengikuti paltihan selanjutnya di masa 
mendatang merupakan indikator yang mendapatkan skor tinggi dalam evaluasi pengabdian. Hal ini dapat mencerminkan bahwa Pokdarwis Kedung Ngancar membutuhkan pelatihan penyusunan proposal bisnis untuk UMKM dalam rangka mengembangkan taman wisata yang lebih baik.

\section{Faktor Pendukung}

Berdasarkan evaluasi hasil kegiatan pengabdian yang dilaksanakan, dapat diidentifikasikan beberapa faktor pendukung kegiatan pengabdian pada masyarakat ini. Beberapa faktor pendukung tersebut adalah pemateri merupakan dosen akuntansi Fakultas Ekonomi, Universitas Negeri Yogyakarta yang juga berkecimpung dalam dunia bisnis sehingga pemateri memiliki pengetahuan terkait penyusunan proposal bisnis untuk pengembangan TWK. Kedua, peserta sangat antusias dengan adanya pelatihan penyusunan proposal bisnis untuk mendapatkan akses pendanaan dan pengembangan desa wisata pada Pokdarwis ini karena mereka membutuhkan pelatihan ini untuk mempersiapkan diri dalam menghadapi persaingan bisnis yang semakin ketat. Ketiga, dukungan dari pihak Pokdarwis Kedung Ngancar terhadap pelaksanaan pelatihan ini dengan membantu memfasilitasi penyelenggaraan pelatihan ini sekaligus menyediakan sarana dan prasana ketika pelaksanaan kegiatan pengabdian ini berlangsung. Terakhir, dukungan dana dari Fakultas Ekonomi UNY guna penyelenggaraan kegiatan pengabdian kepada masyarakat sehingga kegiatan dapat berlangsung dengan baik. Pola kemitraan atau kerja sama antara Pokdarwis dan Tim Pengabdi dari FE UNY akan menguntungkan dalam pengembangan taman wisata (Supriadi, 2018). Oleh karena itu, perlu diperluas kerja sama di bidang lainnya, seperti akomodasi, perjalanan, promosai, pelatihan, dan lain-lain. Kerja sama ini juga dapat diperluas tidak hanya dengan institusi perguruan tingg,i tetapi dapat juga dilakukan dengan pengusaha pariwisata atau dinas pariwisata daerah.

\section{Faktor Penghambat}

Berdasarkan hasil evaluasi kegiatan pengabdian kepada masyarakat yang di selenggarakan di Pokdarwis Kedung Ngancar Bantul teridentifikasi terdapat beberapa faktor penghambat di antaranya adalah kondisi pandemi yang tidak memungkinkan untuk berkumpul dengan jumlah peserta yang terlalu banyak dan terlalu lama membuat kegiatan pelatihan ini terbatas waktunya. Selain itu, keterbatasan waktu penyelenggaraan sehingga diskusi antara tim pengabdi dengan peserta pelatihan mengenai materi yang disampaikan menjadi terbatas dan tidak detail.

\section{Simpulan}

Kegiatan Pelatihan Penyusunan Proposal Bisnis untuk UMKM telah berlangsung dengan baik. Peserta pelatihan berpartisipasi aktif saat sesi tanya jawab dan diskusi. Peserta sangat antusias terhadap materi yang disampaikan oleh tim pengabdi karena peserta merasa materi yang disampaikan sangat penting untuk membantu mereka mengembangkan potensi wisata Kedung Ngancar. Pada akhirnya, pengabdian Pokdarwis berhasil membuat draft proposal bisnis. Selain itu, kapasaitas sumber daya manusia anggota Pokdarwis terkait pengelolaan keuangan menjadi lebih baik. Meskipun secara umum kegiatan pengabdian berhasil, tidak dapat dipungkiri bahwa dalam pelaksanaan program pengabdian masyarakat ini banyak hal yang masih perlu dikembangkan. Keterbatasan interaksi karena adanya pandemi menjadi salah satu pemicu kurang intensifnya kegiatan ini. Perlunya diadakan pendampingan bagi para pelaku Pokdarwis Kedung Ngancar agar dapat menyusun proposal bisnis dan melakukan penawaran investasi melalui teknologi seperti crowdfunding perlu dilakukan secara berkala untuk melihat sejauh mana perkembangan persiapan mereka serta terus memperbaiki persiapan agar sesuai dengan perkembangan zaman dan kondisi perekonomian saat ini. 


\section{Ucapan Terima Kasih}

Pada kesempatan ini, para tim pengabdi mengucapkan terimakasih kepada semua pihak yang telah membantu kegiatan ini, khususnya para Lembaga Penelitian dan Pengabdian Kepada Masyarakat Universitas Negeri Yogyakarta, Fakultas Ekonomi Universitas Negeri Yogyakarta, dan Kelompok Sadar Wisata (Pokdarwis) Taman Wisata Kedung Ngancar yang memberikan kesempatan, bantuan, dukungan, dan kerjasama yang baik sehingga kegaiatn pengabdian dapat berjalan sesuai rencana.

\section{Daftar Pustaka}

Bouncken, R. B., Komorek, M., \& Kraus, S. (2015). Crowdfunding :, 14(3), 407-416.

BPS. (2015). Statistik Indonesia 2015.

Hermawan, H. (2016). Dampak pengembangan desa wisata nglanggeran terhadap ekonomi masyarakat lokal. Jurnal Pariwisata, III(2), 105-117.

Kementerian Keuangan. UNDANG-UNDANG REPUBLIK INDONESIA NOMOR 9 TAHUN 1995 TENTANG USAHA KECIL (1995).

Kuncoro, M. (1996). Manajemen keuangan internasional: Pengantar ekonomi dan bisnis global.

Kuncoro, M. (2014). Otonomi Daerah: Menuju Era Baru Pembangunan Daerah. Penerbit Erlangga.

Pemerintah RI. UNDANG-UNDANG REPUBLIK INDONESIA NOMOR 6 TAHUN 2014 TENTANG DESA (2014).

rmco.id. (2020). Dana Desa Punya Peran Penting Majukan Ekonomi Desa.

Simatupang, P., Togatorop, M., \& Sitompul, R. (1994). Peranan Strategis Industri Kecil Dalam Pembangunan Jangka Panjang Tahap II. In Prosiding Seminar Nasional.

Soetrisno, N. (2003). Koperasi Mewujudkan Kebersamaan dan Kesejahteraan: Menjawab Tantangan Global dan Regional Baru. Jurnal Ekonomi Rakyat, 2(5).

Sunarjaya, I. G., Antara, M., \& Prasiasa, D. P. O. (2018). Kendala pengembangan desa wisata munggu, kecamatan mengwi, badung, 4, 215-227.

Supriadi, B. (2018). Pengembangan Desa Wisata Sebagai Alternatif Peningkatan Kesejahteraan Seminar Nasional Penelitian, ISSN : 20886179 Pengembangan Desa Wisata Sebagai Alternatif Peningkatan Kesejahteraan Masyarakat 382 Peningkatan Kapasitas Penelitian Dalam Memasuki Fase MEA, (October).

Susyanti, D. W., \& Latianingsih, N. (2014). Potensi desa melalui pariwisata pedesaan. Epigram, $11(1), 65-70$. 